\title{
The Effects of $\mathrm{ZnO}_{2}$ Nanoparticles on Properties of Concrete Using Ground Granulated Blast Furnace Slag as Binder
}

\author{
Ali Nazari*, Shadi Riahi \\ Department of Materials Science and Engineering, Saveh Branch, \\ Islamic Azad University, Saveh, Iran
}

Received: October 9, 2010; Revised: June 2, 2011

\begin{abstract}
In the present study, flexural strength together with pore structure, thermal behavior and microstructure of concrete containing ground granulated blast furnace slag with different amount of $\mathrm{ZnO}_{2}$ nanoparticles has been investigated. Portland cement was replaced by different amounts of ground granulated blast furnace slag and the properties of concrete specimens were investigated. Although it negatively impact the properties of concrete, ground granulated blast furnace slag was found to improve the physical and mechanical properties of concrete up to $45 \mathrm{wt}$. (\%). $\mathrm{ZnO}_{2}$ nanoparticles with the average particle size of $15 \mathrm{~nm}$ were added partially to concrete with the optimum content of $45 \mathrm{wt}$. (\%) of ground granulated blast furnace slag and physical and mechanical properties of the specimens was measured. $\mathrm{ZnO}_{2}$ nanoparticle as a partial replacement of cement up to 3 wt. (\%) could accelerate C-S-H gel formation as a result of increased crystalline $\mathrm{Ca}(\mathrm{OH})_{2}$ amount at the early age of hydration and hence increase flexural strength of concrete. The increased the $\mathrm{ZnO}_{2}$ nanoparticles' content more than $3 \mathrm{wt}$. (\%), causes the reduced the flexural strength because of the decreased crystalline $\mathrm{Ca}(\mathrm{OH})_{2}$ content required for C-S-H gel formation together with unsuitable dispersion of nanoparticles in the concrete matrix. $\mathrm{ZnO}_{2}$ nanoparticles could improve the pore structure of concrete and shift the distributed pores to harmless and few-harm pores.
\end{abstract}

Keywords: concrete, ground granulated blast furnace slag, $\mathrm{ZnO}_{2}$ nanoparticles, flexural strength, TGA, $X R D$, pore structure

\section{Introduction}

Nowadays, most industrial slags are being used without taking full advantages of their characteristics or disposed rather than used. Ground granulated blast furnace (GGBFS) has been used for many years as a supplementary cementitious material in Portland cement concrete, either as a mineral admixture or a component of blended cement ${ }^{1}$. GGBFS typically replaces $35-65 \%$ Portland cement in concrete. Thus a $50 \%$ replacement of each ton of Portland cement would result in a reduction of approximately 500,000 t of $\mathrm{CO}_{2}$. Using GGBFS as a partial replacement takes advantage of the energy saving in Portland cement is governed by AASHTO M302 (Standard Specification for Ground Granulated Blast- Furnace Slag for Use in Concrete and Mortars) $)^{2}$. Three types of GGBFS are typically manufactured. They include Portland cement as covered by AASHTO M85 (Standard Specification for Portland Cement) ${ }^{3}$, Portland blast furnace slag cement and slag cement as per AASHTO M240 (Standard Specification for blended Cement) ${ }^{4}$. Utilizing GGBFS as a partial replacement of ordinary Portland cement develops strength and durability of concrete by creating a denser matrix and thereby enhancing the service life of concrete structures. Grinding slag for cement replacement requires only about $25 \%$ energy needed to manufacture Portland cement ${ }^{1}$.

The use of these slags as cementitious components requires only grinding; it will save substantial amounts of energy compared with the production of Portland cement. The partial replacement may decrease the early strength, but increase the later strength and improve microstructure and durability of strengthened Portland cement and concrete considerably ${ }^{5}$. Research results have indicated that clinker less alkali-activated slags show higher strengths, denser structure and better durability than Portland cement under both normal and hydrothermal conditions ${ }^{6-10}$. Thus, the optimum content of these slags is as cementitious material components rather than as aggregates or for base stabilization. Blast furnace slag is a non-metallic material consisting essentially of silicates and aluminosilicates of calcium ${ }^{11}$. It is considerably used in the production of light weight aggregate. When the slag is allowed to cool slowly in the air, it solidifies into gray crystalline material known as crystallized slag. This slag is used as aggregates. When the slag is cooled very rapidly by water, it solidifies and granulates as a granulated slag. The chemical composition of slag can vary over a wide range depending on the nature of the ore, the composition of the limestone flux, coke consumption and the type of iron being made ${ }^{12}$.

Detwiler et al. ${ }^{13}$ investigated the effectiveness of using supplementary cementing materials to increase the chloride resistance of accelerated cured concrete and they found that concretes containing supplementary cementing materials performed better than the Portland cement concretes. As well, use of supplementary cementing materials can also prevent deleterious expansions related to both delayed ettringite formation ${ }^{14}$ and alkali-silica reaction ${ }^{15}$.

There are several works on incorporating nanoparticles into concrete specimens to achieve improved physical and mechanical properties which most of them have focused on using $\mathrm{SiO}_{2}$ nanoparticles ${ }^{16-25}$ and $\mathrm{TiO}_{2}$ nanoparticles ${ }^{26,27}$. There are a few studies on incorporating nano- $\mathrm{Fe}_{2} \mathrm{O}_{3}{ }^{[28]}$, nano- $\mathrm{Al}_{2} \mathrm{O}_{3}{ }^{[29]}$, and nanoclay particles ${ }^{30,31}$. Previously, the effects of $\mathrm{SiO}_{2}{ }^{[32]}, \mathrm{TiO}_{2}{ }^{[33-35]}$ and $\mathrm{ZnO}_{2}{ }^{[36,37]}$ nanoparticles on different properties of self-compacting concrete have been studied. In addition, in a series of works ${ }^{38-43}$, the 
effects of several types of nanoparticles on properties of concrete specimens which are cured in different curing media have been investigated. It has been shown that utilizing nanoparticles in concrete improves the mechanical properties of the specimens besides the improvement in microstructure and pore structure of the concrete specimens. Nanoparticles can act as heterogeneous nuclei for cement pastes, further accelerating cement hydration because of their high reactivity, as nano-reinforcement, and as nano-filler, densifying the microstructure, thereby, leading to a reduced porosity. The most significant issue for all nanoparticles is that of effective dispersion.

Incorporating of other nanoparticles is rarely reported. Therefore, introducing some other nanoparticles which probably could improve the mechanical and physical properties of cementitious composites is inherent.

The aim of this study is investigating flexural strength and pore structure of the concrete incorporating $\mathrm{ZnO}_{2}$ nanoparticles which instead of a main part of its Portland cement, GGBFS has been used. Several specimens with different amount of GGBFS have been prepared and their physical and mechanical properties have been considered.

\section{Materials and Methods}

Ordinary Portland Cement (OPC) conforming to ASTM C150 ${ }^{[44]}$ standard was used as received. The chemical and physical properties of the cement are shown in Table 1.

$\mathrm{ZnO}_{2}$ nanoparticles with average particle size of $15 \mathrm{~nm}$ and $45 \mathrm{~m}^{2} \cdot \mathrm{g}^{-1}$ Blaine fineness producing from Suzhou Fuer Import \& Export Trade Co., Ltd was used as received. The properties of $\mathrm{ZnO}_{2}$ nanoparticles are shown in Table 2.

Crushed limestone aggregates were used to produce selfcompacting concretes, with gravel 4/12 and two types of sand: one coarse $0 / 4$, for fine aggregates and the other fine $0 / 2$, with a very high fines content (particle size $<0.063 \mathrm{~mm}$ ) of $19.2 \%$, the main function of which was to provide a greater volume of fine materials to improve the stability of the fresh concrete.

Ground granulated blast furnace slag was used as a replacement of Portland cement. The chemical composition of the utilized GGBFS has been illustrated in Table 1.

A polycarboxylate with a polyethylene condensate defoamed based admixture (Glenium C303 SCC) was used. Table 3 shows some of the physical and chemical properties of polycarboxylate admixture used in this study.

Totally, two series of mixtures were prepared in the laboratory trials. C0-GGBFS series mixtures were prepared by cement, fine and ultra-fine crushed limestone aggregates with $19.2 \%$ by weight of ultra-fine ones and $0,15,30,45$ and $60 \%$ by weight of GGBFS replaced by Portland cement. N-GGBFS series were prepared with different contents of $\mathrm{ZnO}_{2}$ nanoparticles with average particle size of $15 \mathrm{~nm}$. The mixtures were prepared with the cement replacement by $\mathrm{ZnO}_{2}$ nanoparticles from 1 to $4 \mathrm{wt}$. (\%). To improve workability of the fresh concrete, 1 wt. (\%) of water was replaced by polycarboxylate admixture. The superplasticizer was dissolved in water, and then the nano- $\mathrm{ZnO}_{2}$ was added and stirred at a high speed for 3 minutes.
Though nano- $\mathrm{ZnO}_{2}$ cannot be dissolved in water, a smaller amount of nano- $\mathrm{ZnO}_{2}$ can be dispersed evenly by the superplasticizer. The water to binder ratio for all mixtures was set at 0.40 . The binder content of all mixtures was $450 \mathrm{~kg} \cdot \mathrm{m}^{-3}$. The proportions of the mixtures are presented in Table 4.

The mixing sequence for specimens was consisted of homogenizing the sand and cementitious materials for 1 minute in the mixer and then approximately $75 \%$ of the mixing water were added. The coarse aggregate was introduced and then the superplasticizer was pre-dissolved in the remaining water and was added at the end of the mixing sequence. The total mixing time including homogenizing was 5 minutes.

Several types of tests were carried out on the prepared specimens: a) Flexural strength: Cubic specimens with $100 \mathrm{~mm}$ edge length were made for flexural tests. The moulds were covered with polyethylene sheets and moistened for 24 hours. Then the specimens were demoulded and cured in water at a temperature of $20^{\circ} \mathrm{C}$ in the room condition prior to test days. The flexural strength tests of the samples were determined at 7,28 and 90 days of curing. Flexural tests were carried out according to the ASTM C $39^{[45]}$ standard. After the specified curing period was over, the concrete cubes were subjected to flexural test by using universal testing machine. The tests were carried out triplicately and average flexural strength values were obtained;

b) Mercury intrusion porosimetry: In this study, the pore structure of concrete is evaluated by using MIP. To prepare the samples for MIP measurement, the concrete specimens after 90 days of curing were first broken into smaller pieces, and then the cement paste fragments selected from the center of prisms were used to measure pore structure. The samples were immersed in acetone to stop hydration as fast as possible. Before mercury intrusion test, the samples were dried in an oven at about $110^{\circ} \mathrm{C}$ until constant weight to remove moisture in the pores. MIP is based on the assumption that the non-wetting liquid mercury (the contact angle between mercury and solid is greater than $90^{\circ}$ ) will only intrude in the pores of porous material under pressure $^{46,47}$. Each pore size is quantitatively determined from the relationship between the volume of intruded mercury and the applied pressure ${ }^{47}$. The relationship between the pore diameter and applied pressure is generally described by Washburn equation as follows ${ }^{46,47}$ :

$D=-4 \gamma \cos \theta / P$

where, $\mathrm{D}$ is the pore diameter $(\mathrm{nm}), \gamma$ is the surface tension of mercury $\left(\right.$ dyne. $\left.\mathrm{cm}^{-1}\right), \theta$ is the contact angle between mercury and solid $\left(^{\circ}\right)$ and $P$ is the applied pressure (MPa).

The test apparatus used for pore structure measurement is Auto Pore III mercury porosimeter. Mercury density is 13.5335 g. $\mathrm{mL}^{-1}$. The surface tension of mercury is taken as 485 dynes. $\mathrm{cm}^{-1}$, and the contact angle selected is $130^{\circ}$. The maximum measuring pressure applied is $200 \mathrm{MPa}$ (30000 psi), which means that the smallest pore diameter that can be measured reaches about $6 \mathrm{~nm}$ (on the assumption that all pores have cylindrical shape);

Table 1. Properties of Portland cement and GGBFS (wt. (\%)).

\begin{tabular}{cccccccccc}
\hline Material & $\mathrm{SiO}_{2}$ & $\mathrm{Al}_{2} \mathrm{O}_{3}$ & $\mathrm{Fe}_{2} \mathrm{O}_{3}$ & $\mathrm{CaO}$ & $\mathrm{MgO}$ & $\mathrm{SO}_{3}$ & $\mathrm{Na}_{2} \mathrm{O}$ & $\mathrm{K}_{2} \mathrm{O}$ & Loss on ignition \\
\hline Cement & 21.89 & 5.3 & 3.34 & 53.27 & 6.45 & 3.67 & 0.18 & 0.98 & 3.21 \\
GGBFS & 40.3 & 8.12 & 2.11 & 40.12 & 4.23 & 0.56 & 0.13 & 1.21 & 1.96 \\
\hline
\end{tabular}

Specific gravity of cement: 1.7 g.cm ${ }^{-3}$. 
Table 2. The properties of nano- $\mathrm{ZnO}_{2}$.

\begin{tabular}{cccc}
\hline $\begin{array}{c}\text { Diameter } \\
(\mathrm{nm})\end{array}$ & $\begin{array}{c}\text { Surface volume ratio } \\
\left(\mathrm{m}^{2} \cdot \mathrm{g}^{-1}\right)\end{array}$ & $\begin{array}{c}\text { Density } \\
\left(\mathrm{g} . \mathrm{cm}^{-3}\right)\end{array}$ & $\begin{array}{c}\text { Purity } \\
(\%)\end{array}$ \\
\hline $15 \pm 4$ & $166 \pm 17$ & $<0.10$ & $>99.9$ \\
\hline
\end{tabular}

Table 3. Physical and chemical characteristics of the polycarboxylate admixture.

\begin{tabular}{cc}
\hline Appearance & Yellow-brown liquid \\
\hline$\%$ solid residue & Approximately $36 \%$ \\
$\mathrm{pH}$ & $5.2-5.3$ \\
Specific gravity $\left(\mathrm{kg} . \mathrm{L}^{-1}\right)$ & Approximately 1.06 \\
Rotational viscosity $(\mathrm{MPa})$ & 79.30 \\
$\% \mathrm{C}$ & 52.25 \\
$\mathrm{ppm} \mathrm{Na}$ & 9150 \\
$\mathrm{ppm} \mathrm{K} \mathrm{K}^{+}$ & 158 \\
\hline
\end{tabular}

Table 4. Mixture proportion of nano- $\mathrm{ZnO}_{2}$ particles blended concretes.

\begin{tabular}{|c|c|c|c|}
\hline \multirow{2}{*}{$\begin{array}{c}\text { Sample } \\
\text { designation }\end{array}$} & \multirow{2}{*}{$\begin{array}{c}\mathrm{ZnO}_{2} \\
\text { nanoparticles } \\
(\%)\end{array}$} & \multicolumn{2}{|c|}{ Quantities (kg.m ${ }^{-3}$ ) } \\
\hline & & Cement & $\begin{array}{c}\mathrm{ZnO}_{2} \\
\text { nanoparticles }\end{array}$ \\
\hline C0-GGBFS0 & 0 & 450 & 0 \\
\hline C0-GGBFS15 & 0 & 450 & 0 \\
\hline C0-GGBFS30 & 0 & 450 & 0 \\
\hline C0-GGBFS45 & 0 & 450 & 0 \\
\hline C0-GGBFS60 & 0 & 450 & 0 \\
\hline N1- GGBFS & 1 & 445.5 & 4.5 \\
\hline N2- GGBFS & 2 & 441.0 & 9.0 \\
\hline N3- GGBFS & 3 & 437.5 & 13.5 \\
\hline N4- GGBFS & 4 & 432.0 & 18.0 \\
\hline
\end{tabular}

Water to binder [cement + nano- $\mathrm{ZnO}_{2}$ ] ratio of 0.40 .

c) Scanning electron microscopy (SEM): SEM investigations were conducted on a Hitachi apparatus. Backscattered electron (BSE) and secondary electron (SE) imaging was used to study the samples, which were prepared under conditions that ensured their subsequent viability for analytical purposes; and

d) X-ray diffraction (XRD): A Philips PW-1730 unit was used for $\mathrm{XRD}$ analysis which was taken from 4 to $70^{\circ}$.

\section{Results and Discussion}

\subsection{Properties of CO-GGBFS specimens}

Table 5 shows the flexural strength of $\mathrm{C} 0$ - GGBFS specimens after 7, 28 and 90 days of curing which are all increased by increasing GGBFS up to $45 \%$. Using more than $45 \%$ GGBFS has reduced the flexural strength of the specimens and it may be as a result of the reduced $\mathrm{CaO}$ content in GGBFS in comparison with Portland cement. This may be reduce the amount of crystalline $\mathrm{Ca}(\mathrm{OH})_{2}$ and hence C-S-H gel. This fact may be due to various factors, such as using different superplasticizers or greater fines content in the concrete specimens. Roncero and $\mathrm{Gettu}^{48}$ have pointed out the formation of large $\mathrm{CH}$ crystals by using polycarboxylate superplasticizers. These large crystals weaken the aggregate-paste transition zone and hence
Table 5. Flexural strength of C0-GGBFS and N-GGBFS specimens.

\begin{tabular}{ccccc}
\hline \multirow{2}{*}{$\begin{array}{c}\text { Sample } \\
\text { designation }\end{array}$} & $\begin{array}{c}\mathrm{ZnO}_{2} \\
\text { nanoparticles } \\
(\%)\end{array}$ & \multicolumn{3}{c}{ Flexural strength (MPa) } \\
\cline { 3 - 5 } & 0 & $3.7 \pm 0.2$ & $4.2 \pm 0.2$ & $5.6 \pm 0.4$ \\
\hline C0-GGBFS0 & 0 & $3.5 \pm 0.2$ & $4.6 \pm 0.3$ & $6.2 \pm 0.3$ \\
C0-GGBFS15 & 0 & $3.1 \pm 0.1$ & $4.9 \pm 0.4$ & $6.8 \pm 0.4$ \\
C0-GGBFS30 & 0 & $2.8 \pm 0.2$ & $5.4 \pm 0.3$ & $7.3 \pm 0.5$ \\
C0-GGBFS45 & 0 & $2.5 \pm 0.1$ & $5.1 \pm 0.4$ & $7.0 \pm 0.4$ \\
C0-GGBFS60 & 0 & $3.5 \pm 0.2$ & $5.1 \pm 0.4$ & $6.7 \pm 0.3$ \\
N1- GGBFS & 1 & $3.8 \pm 0.3$ & $5.5 \pm 0.3$ & $7.1 \pm 0.4$ \\
N2- GGBFS & 2 & $4.3 \pm 0.2$ & $6.2 \pm 0.4$ & $7.6 \pm 0.4$ \\
N3- GGBFS & 3 & $4.0 \pm 0.3$ & $5.6 \pm 0.3$ & $7.2 \pm 0.5$ \\
N4- GGBFS & 4 & & & \\
\hline
\end{tabular}

decrease the flexural strength of concrete by decreasing the aggregatepaste bond. As for the influence of the fines content, the bigger this is the greater the shrinkage becomes ${ }^{49-53}$, giving rise to the appearance of a greater number of micro-cracks in the aggregate paste interface which also reduce the flexural strength. Moreover, by increasing the volume of fines, the specific surface area of the aggregates increases, with the aggregate-paste transition zone is being precisely the weakest phase of the concrete.

Table 6 shows that with increasing GGBFS content, the total specific pore volumes of concretes are decreased and the most probable pore diameters of concretes shift to smaller pores and fall in the range of few-harm pore, which indicates that the addition of GGBFS refines the pore structure of concretes.

Table 6 also gives the porosities, average diameters and median diameters (volume) of various concretes. The regularity of porosity is similar to that of total specific pore volume. The regularity of average diameter and median diameter (volume) is similar to that of most probable pore diameter.

The pore size distribution of concretes is shown in Table 6. It is seen that by increasing GGBFS content, the amounts of pores decrease, which shows that the density of concretes is increased and the pore structure is improved.

Figure 1 shows XRD analysis of C0-GGBFS specimens at different times after curing. As Figure 1 also shows, the peak related to formation of the hydrated products shifts to appear in earlier times indicating the positive impact of $\mathrm{PC}$ on formation of $\mathrm{Ca}(\mathrm{OH})_{2}$ and C-S-H gel.

Finally, Figure 2 shows SEM micrographs of C0-GGBFS specimens without and with GGBFS. The morphological analysis evinced no significant differences in the form and the texture of the different reaction products in pastes with and without admixtures. This may be due to using superplasticizer which helps self compactibility of the specimens. The beneficial effects of GGBFS in concrete results from the modified microstructure of cementitious paste, which has more capillary pores, filled with low density $\mathrm{C}-\mathrm{S}-\mathrm{H}$ gel than Portland cement paste ${ }^{54-56}$. It can be observed that GGBFS can be effectively used to reduce the pore sizes and cumulative pore volume ${ }^{57}$. It appears that higher GGBFS replacement percentage has denser structure and prevents concrete from water penetration. The GGBFS reacts with water in alkali environment and then with calcium hydroxide to form cement hydration product through pozzolanic reaction to form extra $\mathrm{C}-\mathrm{S}-\mathrm{H}$ gel in the paste and slow down the strength development at early age. Denser microstructure or lower porosity results from higher $\mathrm{C}-\mathrm{S}-\mathrm{H}$ content that represents higher GGBFS replacement percentage and higher durability of concrete. 
Table 6. Properties of the pores in C0-GGBFS and N-GGBFS specimens.

\begin{tabular}{|c|c|c|c|c|c|c|c|c|c|}
\hline \multirow{2}{*}{$\begin{array}{c}\text { Sample } \\
\text { designation }\end{array}$} & \multirow{2}{*}{$\begin{array}{l}\text { Total specific } \\
\text { pore volume } \\
\left(\mathrm{mL} \cdot \mathrm{g}^{-1}\right)\end{array}$} & \multirow{2}{*}{$\begin{array}{l}\text { Most probable } \\
\text { pore diameter } \\
\quad(\mathrm{nm})\end{array}$} & \multirow{2}{*}{$\begin{array}{c}\text { Prosity } \\
(\%)\end{array}$} & \multirow{2}{*}{$\begin{array}{l}\text { Average } \\
\text { diameter } \\
(\mathrm{nm})\end{array}$} & \multirow{2}{*}{$\begin{array}{c}\text { Median } \\
\text { diameter } \\
\text { (volume) } \\
(\mathrm{nm})\end{array}$} & \multicolumn{4}{|c|}{ Pore size distribution $\left(\mathrm{mL} \cdot \mathrm{g}^{-1}(\%)\right)$} \\
\hline & & & & & & $\begin{array}{c}\text { Pore size } \\
\text { distribution } \\
\left(\mathrm{mL} \cdot \mathrm{g}^{-1}(\%)\right)\end{array}$ & $\begin{array}{c}\text { Few-harm } \\
\text { pores } \\
(20 \sim 50 \mathrm{~nm})\end{array}$ & $\begin{array}{c}\text { Harmful } \\
\text { pores } \\
(50 \sim 200 \mathrm{~nm})\end{array}$ & $\begin{array}{l}\text { Multi-harm } \\
\text { pores } \\
(>200 \mathrm{~nm})\end{array}$ \\
\hline C0-GGBFSO & 0.0323 & 16.0 & 9.14 & 11.6 & 25.7 & 0.0044 & 0.0098 & 0.0116 & 0.0041 \\
\hline C0-GGBFS15 & 0.0298 & 13.0 & 7.01 & 9.8 & 21.3 & 0.0036 & 0.0086 & 0.0095 & 0.0034 \\
\hline C0-GGBFS30 & 0.0284 & 13.0 & 6.88 & 9.3 & 20.9 & 0.0035 & 0.0084 & 0.0091 & 0.0033 \\
\hline C0-GGBFS45 & 0.0270 & 12.0 & 6.70 & 8.6 & 19.1 & 0.0030 & 0.0080 & 0.0083 & 0.0030 \\
\hline C0-GGBFS60 & 0.0279 & 13.0 & 6.76 & 8.9 & 19.6 & 0.0032 & 0.0082 & 0.0086 & 0.0031 \\
\hline N1- GGBFS & 0.0245 & 10.5 & 6.29 & 7.6 & 17.5 & 0.0028 & 0.0073 & 0.0075 & 0.0029 \\
\hline N2- GGBFS & 0.0232 & 9.5 & 6.13 & 7.0 & 16.9 & 0.0025 & 0.0067 & 0.0068 & 0.0025 \\
\hline N3- GGBFS & 0.0220 & 9.5 & 6.03 & 6.3 & 16.0 & 0.0021 & 0.0063 & 0.0066 & 0.0023 \\
\hline N4- GGBFS & 0.0227 & 10.5 & 6.07 & 6.6 & 16.4 & 0.0022 & 0.0066 & 0.0067 & 0.0024 \\
\hline
\end{tabular}

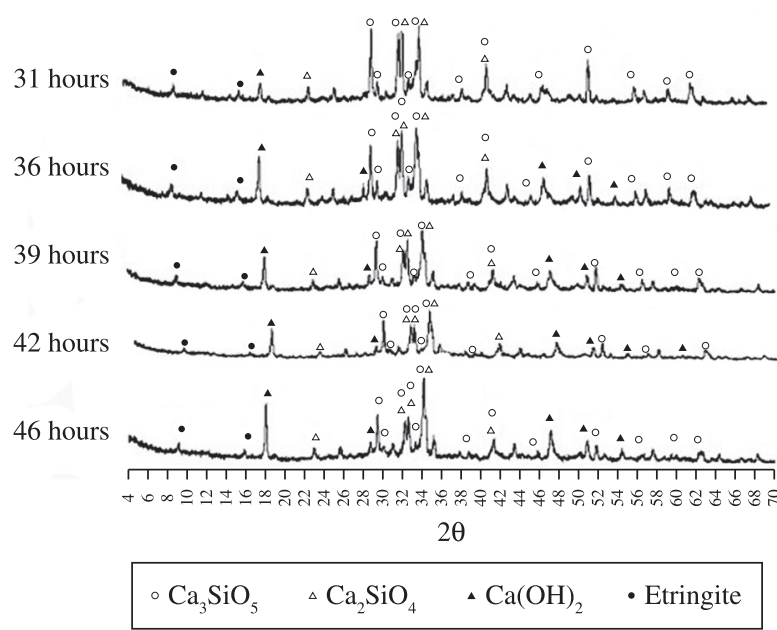

Figure 1. XRD results indicating the formation of hydrated products for different C0-GGBFS specimens: a) C0-GGBFS0; b) C0-GGBFS15; c) C0-GGBFS30; d) C0-GGBFS45; and e) C0-GGBFS60.

Portland cement is usually used with GGBFS and the hydration product of $\mathrm{Ca}(\mathrm{OH})_{2}$ activates the slag hydration to from a mixture of low $\mathrm{CaO} / \mathrm{SiO}_{2}(\mathrm{C} / \mathrm{S})$ ratio $\mathrm{CaO}-\mathrm{SiO}_{2}-\mathrm{H}_{2} \mathrm{O}(\mathrm{C}-\mathrm{S}-\mathrm{H})$ and $\mathrm{AF}_{\mathrm{m}}$ (cementitious product from the reaction of reactive alumina and calcium hydroxide) phases. Pozzolanic reaction is also found to increase the $\mathrm{C} / \mathrm{S}$ ratio to a value of about 1.7 in slag-cement blends due to unstable low calcium $\mathrm{C}-\mathrm{S}-\mathrm{H}$ and $\mathrm{Ca}(\mathrm{OH})_{2}$ mixture. When supplementary cementitious material like GGBFS is used in concrete, they do not only reduce the porosity but also the pores become finer and the change in mineralogy of the cement hydrates leads to the reduction in mobility of chloride ions.

Since it has been found that using 45\% GGBFS instead of Portland cement produces a suitable specimen with the optimum properties, $\mathrm{ZnO}_{2}$ nanoparticles with different amounts of replacement by Portland cement were added to the specimens containing 45 wt. (\%) GGBFS and their properties have been investigated in the following section.

\subsection{Properties of $N-G G B F S$ specimens}

Table 5 shows the flexural strength of N-GGBFS specimens after 7, 28 and 90 days of curing. The results show that the flexural strength increases by adding $\mathrm{ZnO}_{2}$ nanoparticles up to $3.0 \mathrm{wt}$. (\%) replacements (N3-GGBFS series) and then it decreases, although adding 4.0 percent $\mathrm{ZnO}_{2}$ nanoparticles produces specimens with much higher flexural strength with respect to the all other C0-GGBFS concretes. In the previous works ${ }^{33-43}$ it was shown that using up to $4.0 \mathrm{wt}$. (\%) of nanoparticles in self compacting concrete could improve the flexural strength of the specimens. However, in this work an optimum level of 3.0 wt. (\%) was achieved by utilizing GGBFS. This may be due to the reduction of $\mathrm{CaO}$ content when GGBFS is used (Table 1). Thus, the amount of crystalline $\mathrm{Ca}(\mathrm{OH})_{2}$ is reduced and the amount of $\mathrm{ZnO}_{2}$ nanoparticles assist to formation C-S-H gel is decreased. Hence, addition more than 3.0 wt. (\%) of $\mathrm{ZnO}_{2}$ nanoparticles may decrease the flexural strength of N-GGBFS specimens. Also, the reduced flexural strength by adding more than 3 wt. (\%) $\mathrm{ZnO}_{2}$ nanoparticles may be due to the defects generated in dispersion of nanoparticles that causes weak zones.

The higher flexural strength in the N-GGBFS series mixtures with respect to C0-GGBFS series is due to the rapid consumption of crystalline $\mathrm{Ca}(\mathrm{OH})_{2}$ which quickly are formed during hydration of Portland cement specially at early ages as a result of high reactivity of $\mathrm{ZnO}_{2}$ nanoparticles. As a consequence, the hydration of cement is accelerated and larger volumes of reaction products are formed. Also $\mathrm{ZnO}_{2}$ nanoparticles recover the particle packing density of the blended cement, directing to a reduced volume of larger pores in the cement paste.

Table 6 shows that with increasing $\mathrm{ZnO}_{2}$ nanoparticles up to $3 \mathrm{wt}$. (\%), the total specific pore volumes of concretes are decreased, and the most probable pore diameters of concretes shift to smaller pores and fall in the range of few-harm pore, which indicates that the addition of $\mathrm{PC}$ refines the pore structure of concretes.

Table 6 gives the porosities, average diameters and median diameters (volume) of various concretes. The regularity of porosity is similar to that of total specific pore volume. The regularity of average diameter and median diameter (volume) is similar to that of most probable pore diameter.

The pore size distribution of concretes is shown in Table 6. It is observed that by adding nanoparticles, the amounts of is pores decreased, which shows that the density of concretes is increased and the pore structure is improved.

The effectiveness of nano- $\mathrm{ZnO}_{2}$ in improving the pore structure of concretes increases in the order: N1-GGBFS < N2-GGBFS < N4-GGBFS $<$ N3-GGBFS. With increasing the nanoparticles' content, the reduced extent of pores in concretes is all decreased, and the improvement on the pore structure of concretes is weakening. 

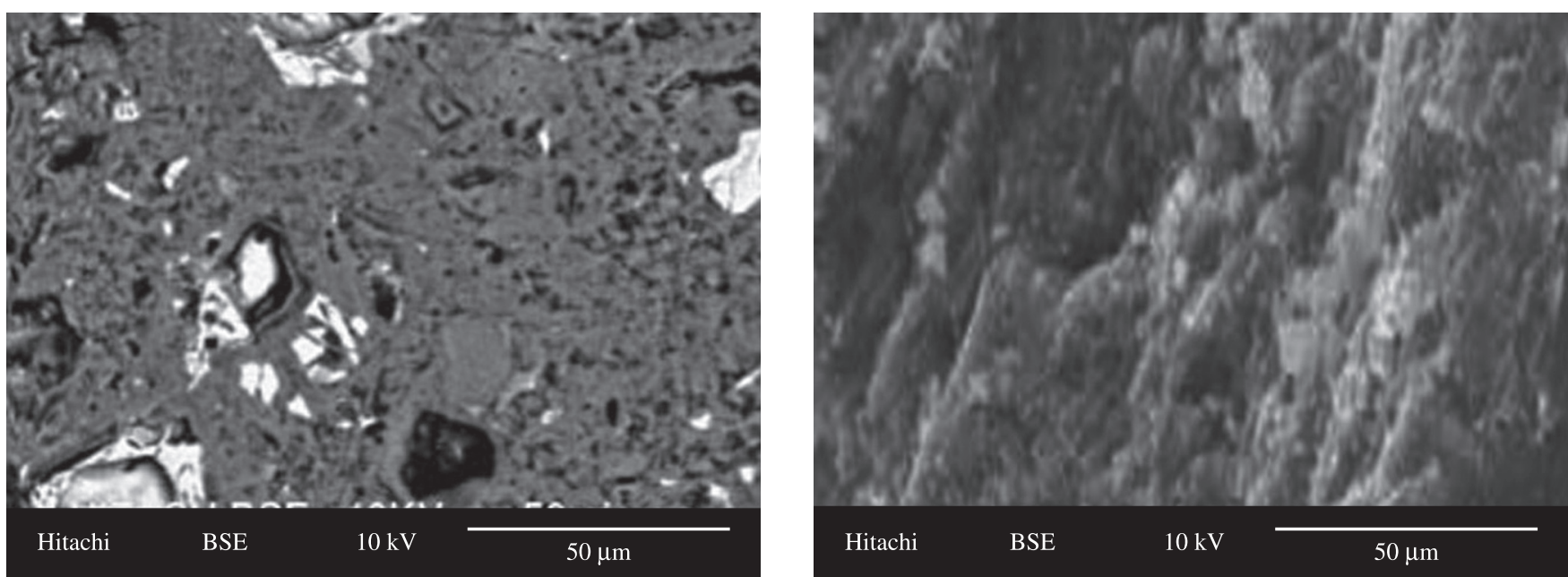

(1)
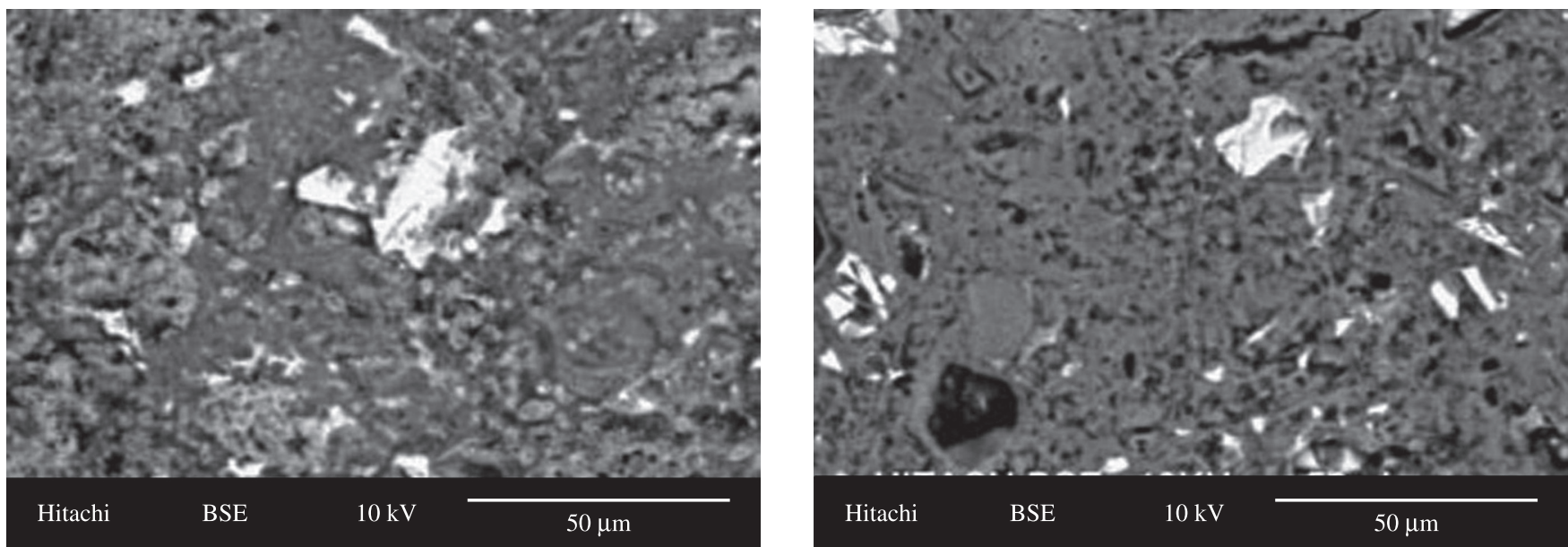

(2)
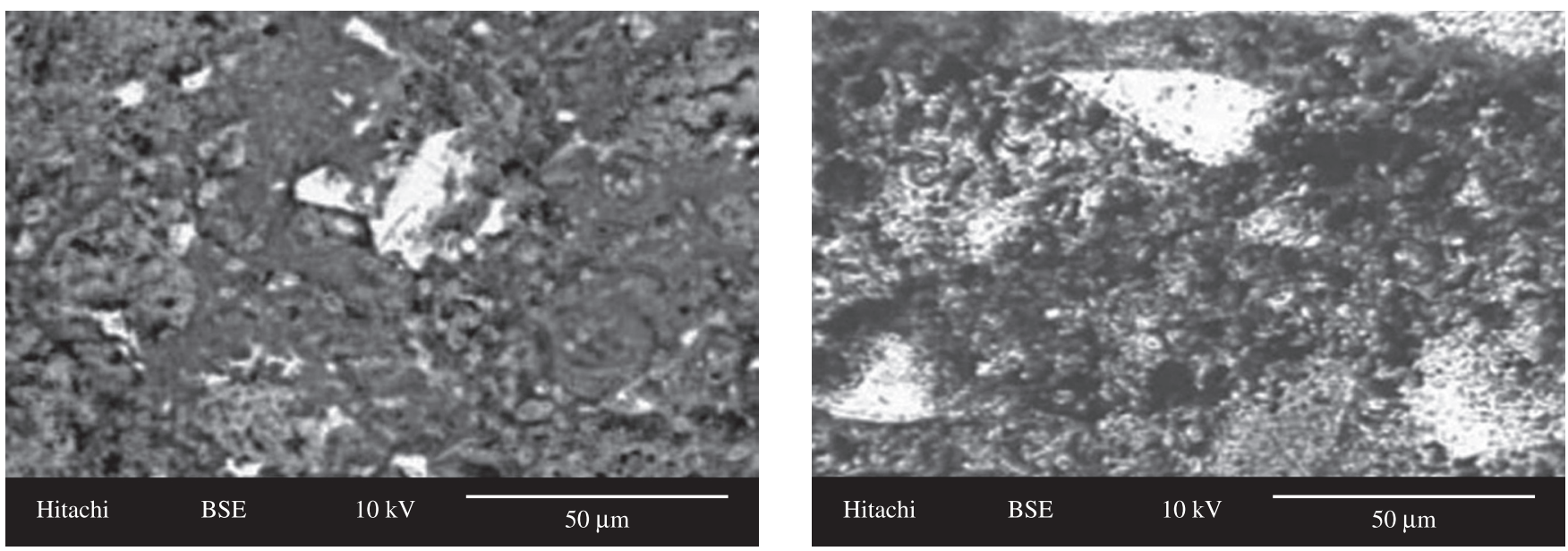

(a)

(3)

Figure 2. SEM micrographs of a) C0-GGBFS0 specimen; and b) C0-GGBFS45 specimen at 7 days (series 1), 28 days (series 2) and 90 days (series 3 ) of curing.

The mechanism that the nanoparticles improve the pore structure of concrete can be interpreted as follows ${ }^{58}$ : Suppose that nanoparticles are uniformly dispersed in concrete and each particle is contained in a cube pattern, therefore the distance between nanoparticles can be determined. After the hydration begins, hydrate products diffuse and envelop nanoparticles as kernel ${ }^{58}$. If the content of nanoparticles and the distance between them are appropriate, the crystallization will be controlled to be a suitable state through restricting the growth of 


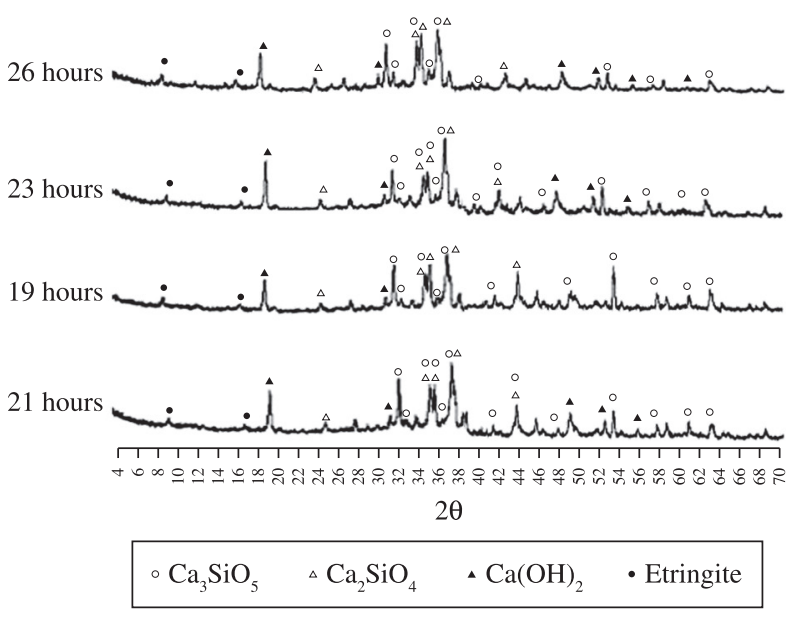

Figure 3. XRD results indicating the formation of hydrated products for different N-GGBFS specimens: a) N1-GGBFS; b) N2-GGBFS; c) N3-GGBFS; and d) N4-GGBFS

$\mathrm{Ca}(\mathrm{OH})_{2}$ crystal by nanoparticles. Moreover, the nanoparticles located in cement paste as kernel can further promote cement hydration due to their high activity. This makes the cement matrix more homogeneous and compact. Consequently, the pore structure of concrete is improved evidently such as the concrete containing nano- $\mathrm{ZnO}_{2}$ in the amount of $1 \%$ by weight of binder ${ }^{58}$

With increasing the content of $\mathrm{ZnO}_{2}$ nanoparticles more than $3 \mathrm{wt}$. (\%), the improvement on the pore structure of concrete is weakened. This can be attributed to that the distance between nanoparticles decreases with increasing content of nanoparticles, and $\mathrm{Ca}(\mathrm{OH})_{2}$ crystal cannot grow up enough due to limited space and the crystal quantity is decreased, which leads to the ratio of crystal to strengthening gel small and the shrinkage and creep of cement matrix increased ${ }^{59}$, thus the pore structure of cement matrix is looser relatively.

On the whole, the addition of nanoparticles improves the pore structure of concrete. On the one hand, nanoparticles can act as a filler to enhance the density of concrete, which leads to the porosity of concrete reduced significantly. On the other hand, nanoparticles can not only act as an activator to accelerate cement hydration due to their high activity, but also act as a kernel in cement paste which makes the size of $\mathrm{Ca}(\mathrm{OH})_{2}$ crystal smaller and the tropism more stochastic.

Figure 3 shows XRD analysis of N-GGBFS specimens at different times after curing. As Figure 3 also shows, the peak related to formation of the hydrated products shifts to appear in earlier times indicating the positive impact of $\mathrm{PC}$ on formation of $\mathrm{Ca}(\mathrm{OH})_{2}$ and C-S-H gel at early age of cement hydration.

Finally, Figure 4 show SEM micrographs of N-GGBFS specimens containing 3 wt. (\%) of $\mathrm{ZnO}_{2}$ nanoparticles. Figure 4 shows a more compact mixture after all days of curing which indicate rapid formation of C-S-H gel in presence of $\mathrm{ZnO}_{2}$ nanoparticles.

Although, as indicated, the larger volume of $\mathrm{ZnO}_{2}$ nanoparticles than 3 wt. (\%) reduces the flexural strength due to reduction of hydrated lime with respect to the $\mathrm{ZnO}_{2}$ nanoparticle content in addition to the deficiency occurred during dispersion of $\mathrm{ZnO}_{2}$ nanoparticles in the cement paste.

Several studies have been conducted on flexural strength of cementitious composites reinforced by $\mathrm{ZnO}_{2}$ nano-particles and some possible reasons have been represented to show the increment of flexural strength:

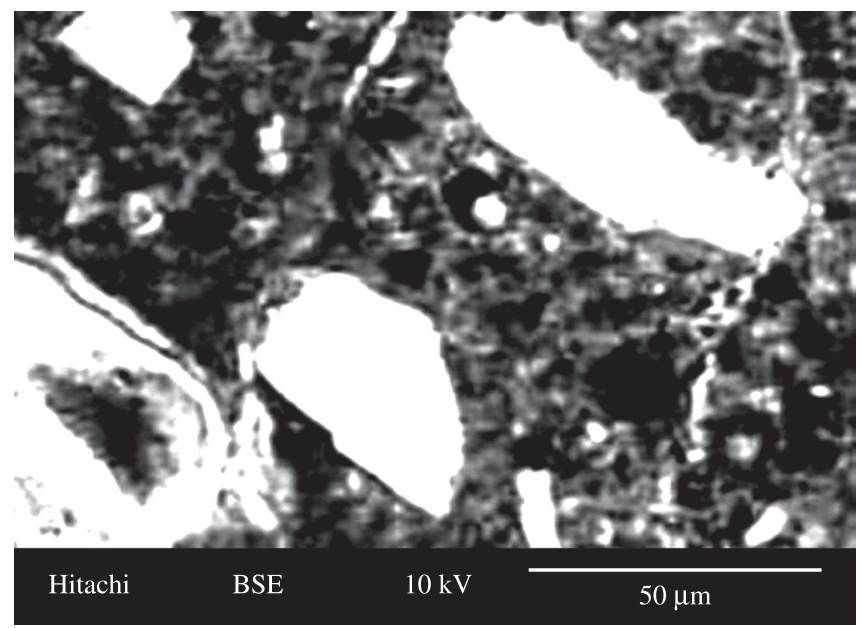

(a)

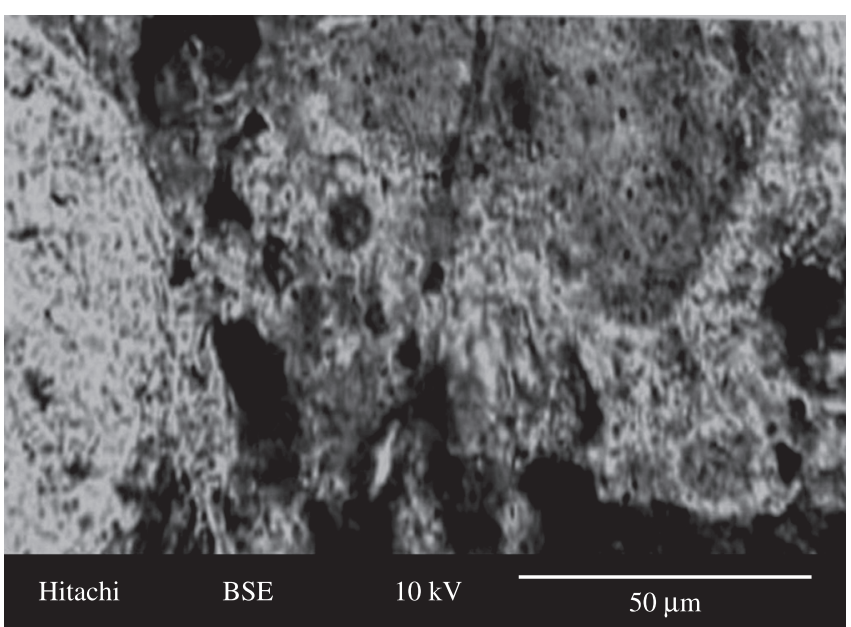

(b)

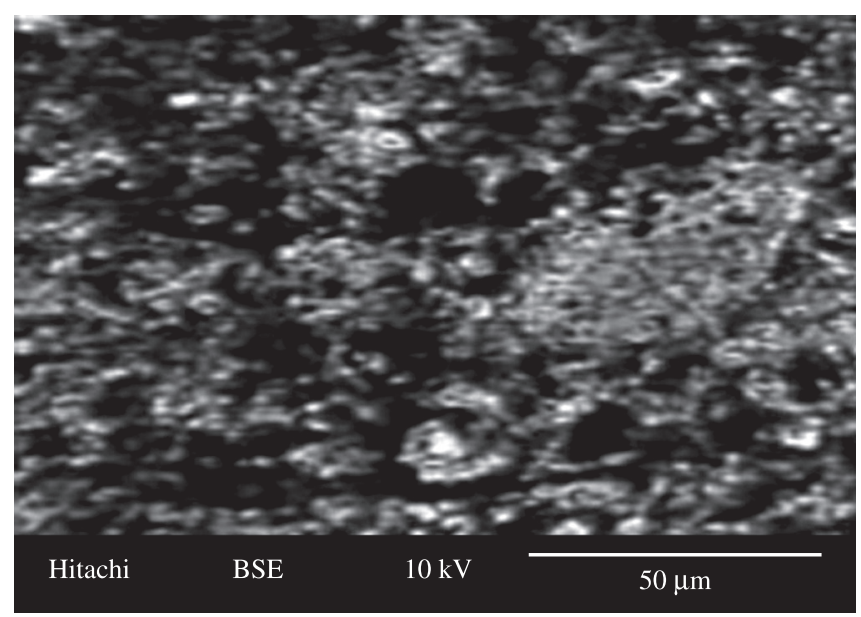

(c)

Figure 4. SEM micrographs of a) N3-GGBFS specimen at 7 days (1); 28 days (2); and 90 days (3) of curing.

1. When a small amount of the nano-particles is uniformly dispersed in the cement paste, the nano-particles act as a nucleus to tightly bond with cement hydrate and further promote cement hydration due to their high activity, which is favorable for the strength of cement mortar ${ }^{29}$; 
2. The nano-particles among the hydrate products will prevent crystals from growing which are positive for the strength of cement paste ${ }^{29,60,61}$; and

3. The nano-particles fill the cement pores, thus increasing the strength. Nano- $\mathrm{ZnO}_{2}$ can contribute in the hydration process to generate $\mathrm{C}-\mathrm{S}-\mathrm{H}$ through reaction with $\mathrm{Ca}(\mathrm{OH})_{2}^{[62,63]}$.

\section{Conclusions}

The results obtained in this study can be summarized as follows:

- The increased the GGBFS content up to $45 \mathrm{wt}$. (\%) results in the increased the flexural strength. It has been argued that utilizing GGBFS content more than $45 \mathrm{wt}$. (\%) reduces the amount of $\mathrm{CaO}$ which is required for $\mathrm{Ca}(\mathrm{OH})_{2}$ and subsequent C-S-H gel. In addition, the pore structure of concrete specimens is found to improve with adding up to $45 \mathrm{wt}$. (\%) GGBFS;

- As the content of $\mathrm{ZnO}_{2}$ nanoparticles is increased up to 3 wt. (\%), the flexural strength of the specimens is increased. This is due to more formation of hydrated products in presence of $\mathrm{ZnO}_{2}$ nanoparticles. More rapid formation of hydrated products in presence of $\mathrm{ZnO}_{2}$ nanoparticles was confirmed by $\mathrm{XRD}$ results. The pore structure of self compacting concrete containing $\mathrm{ZnO}_{2}$ nanoparticles is improved and the content of all mesopores and macropores is increased.

\section{References}

1. Shi C and Qian J. High performance cementing materials from industrial slags: a review. Resources, Conservation and Recycling. 2000; 29:195-207. http://dx.doi.org/10.1016/S0921-3449(99)00060-9

2. Smith MA. The economic and environmental benefits of increased use of pfa and granulated slag. Resources Policy. 1975; 1(3): 154-170. http://dx.doi.org/10.1016/0301-4207(75)90030-6

3. Collins RJ and Ciesielski SK. Recycling and Use of Waste Materials and By-Products in Highway Construction. Washington: Transportation Research Board; 1994. National Cooperative Highway Research Program Synthesis of Highway Practice, n. 199.

4. Afrani I and Rogers C. The Effects of Different Cementing Materials and Curing on Concrete Scaling. Cement Concrete and Aggregates. 1994; 16(2):132-139.

5. Malhotra VM. Properties of fresh and hardened concrete incorporating ground granulated blast furnace slag. In: Malhotra VM, editor. Supplementary Cementing Materials for Concrete. Canada: Minister of Supply and Services; 1987. p. 291-336.

6. Isozaki K. Some properties of alkali-activated slag cements. CAJ Revista. 1986; 120-123.

7. Deng Y, Wu X and Tang M. High strength alkali-slag cement. Journal of Nanjing University of Chemical Technology. 1989; 11(2):1-7.

8. Shi C, Wu X and Tang M. Hydration of alkali-slag cements at $150{ }^{\circ} \mathrm{C}$. Cement and Concrete Research. 1991; 21:91-100. http://dx.doi. org/10.1016/0008-8846(91)90035-G

9. Deja J and Malolepszy J. Resistance of alkali-activated slag mortars to chloride solution. In: Proceedings of the Third International Conference on the Use of Fly Ash, Silica Fume, Slag and Natural Pozzolans in Concrete; 1989; Norway, Chicago. Norway: American Concrete Institute; 1989. p. 1547-1561.

10. Shi $\mathrm{C}$, Shen $\mathrm{X}, \mathrm{Wu} X$ and Tang M. Immobilization of radioactivewastes with Portland and alkali-slag cement pastes. Cemento. 1994; 91(2):97-108.

11. RILEM TC 73-SBC Committee. Siliceous by-products for use in concrete. Materials and Structures. 1988; 21(1):69-80. http://dx.doi.org/10.1007/ BF02472530

12. Sohaib MM, Ahmed SA and Balaha MM. Effect of fire and cooling mode on the properties of slag mortars. Cement and Concrete Research. 2001; 31(11):1533-1538. http://dx.doi.org/10.1016/S0008-8846(01)00561-0
13. Detwiler RJ, Fapohunda CA and Natale J. Use of supplementary cementing materials to increase the resistance to chloride ion penetration of concretes cured at elevated temperatures. ACI Materials Journal. 1994; 91(1):63-66.

14. Ramlochan T, Zacarias P, Thomas MDA and Hooton RD. The effect of pozzolans and slag on the expansion of mortars cured at elevated temperature: part I expansive behaviour. Cement and Concrete Research. 2003; 33(6):807-814. http://dx.doi.org/10.1016/S0008-8846(02)01066-9

15. Bleszynski RF, Hooton RD, Thomas MDA and Rogers CA. Durability of ternary blend concretes with silica fume and blast furnace slag: laboratory and outdoor exposure site studies. ACI Materials Journal. 2002; 99(5):499-508.

16. Bjornstrom J, Martinelli A, Matic A, Borjesson L and Panas I. Accelerating effects of colloidal nano-silica for beneficial calcium-silicate-hydrate formation in cement. Chemical Physics Letters. 2004; 392(1-3):242-248.

17. Ji T. Preliminary study on the water permeability and microstructure of concrete incorporating nano- $\mathrm{SiO}_{2}$. Cement and Concrete Research. 2005; 35(10):1943-7. http://dx.doi.org/10.1016/j.cemconres.2005.07.004

18. Jo B-W, Kim C-H, Tae G-h, Park J-B. Characteristics of cement mortar with nano-SiO2 particles. Construction and Building Materials. 2007; 21(6):1351-5. http://dx.doi.org/10.1016/j.conbuildmat.2005.12.020

19. Li H, Xiao H-g and Ou J-p. A study on mechanical and pressure-sensitive properties of cement mortar with nanophase materials. Cement and Concrete Research. 2004; 34(3):435-8. http://dx.doi.org/10.1016/j. cemconres.2003.08.025

20. Li H, Zhang M-h and Ou J-P. Abrasion resistance of concrete containing nanoparticles for pavement. Wear. 2006; 260(11-12):1262-6. http://dx.doi. org/10.1016/j.wear.2005.08.006

21. Qing Y, Zenan Z, Deyu K and Rongshen C. Influence of nano-SiO, addition on properties of hardened cement paste as compared with silica fume. Construction and Building Materials. 2007; 21(3):539-45. http://dx.doi.org/10.1016/j.conbuildmat.2005.09.001

22. Lin KL, Chang WC, Lin DF, Luo HL and Tsai MC. Effects of nano-SiO and different ash particle sizes on sludge ash-cement mortar. Journal of Environmental Management. 2008; 88(4):708-14. PMid:17498863. http://dx.doi.org/10.1016/j.jenvman.2007.03.036

23. Lin DF, Lin KL, Chang WC, Luo HL and Cai MQ. Improvements of nano$\mathrm{SiO}_{2}$ on sludge/fly ash mortar. Waste Management. 2008; 28(6):1081-7. PMid:17512717. http://dx.doi.org/10.1016/j.wasman.2007.03.023

24. Sobolev K, Flores I, Torres-Martinez LM, Valdez PL, Zarazua E, Cuellar EL. Engineering of $\mathrm{SiO}_{2}$ nanoparticles for optimal performance in nano cementbased materials. In: Bittnar Z, Bartos PJM, Nemecek J, Smilauer $\mathrm{V}$ and Zeman J, editors. Nanotechnology in construction: proceedings of the NICOM3 ( $3^{\text {rd }}$ international symposium on nanotechnology in construction). Prague, Czech Republic; 2009. p. 139-48.

25. Qing Y, Zenan Z, Li S and Rongshen C. A comparative study on the pozzolanic activity between nano- $\mathrm{SiO}_{2}$ and silica fume. Journal of Wuhan University of Technology - Materials Science Edition. 2008; 21(3):153-7.

26. Sobolev K and Ferrada-Gutiérrez M. How nanotechnology can change the concrete world: part 2. American Ceramic Society Bulletin. 2005; 84(11):16-9.

27. Li H, Zhang M-h and Ou J-p. Flexural fatigue performance of concrete containing nano-particles for pavement. International Journal of Fatigue. 2007; 29(7):1292-301. http://dx.doi.org/10.1016/j.ijfatigue.2006.10.004

28. Li Z, Wang H, He S, Lu Y and Wang M. Investigations on the preparation and mechanical properties of the nano-alumina reinforced cement composite. Materials Letters. 2006; 60(3):356-9.

29. Garboczi EJ and Bentz DP. Modelling of the microstructure and transport properties of concrete. Construction and Building Materials. 1996; 10(5):293-300. http://dx.doi.org/10.1016/j.matlet.2005.08.061

30. Chang T-P, Shih J-Y, Yang K-M and Hsiao T-C. Material properties of Portland cement paste with nano-montmorillonite. Journal Materials Science. 2007; 42(17):7478-87. http://dx.doi.org/10.1007/s10853-006-1462-0 
31. Kuo W-Y, Huang J-S and Lin C-H. Effects of organo-modified montmorillonite on strengths and permeability of cement mortars. Cement and Concrete Research 2006; 36(5):886-95. http://dx.doi.org/10.1016/j. cemconres.2005.11.013

32. Nazari A and Riahi S. Microstructural, thermal, physical and mechanical behavior of the self compacting concrete containing $\mathrm{SiO}_{2}$ nanoparticles. Materials Science and Engineering: A. 2010; 527:7663-7672. http://dx.doi.org/10.1016/j.msea.2010.08.095

33. Nazari A and Riahi S. The Effects of $\mathrm{TiO}_{2}$ Nanoparticles on Flexural Damage of Self-compacting Concrete. International Journal of Damage Mechanics. 2010; 29. http://dx.doi.org/10.1177/1056789510385262

34. Nazari A and Riahi S. The effect of $\mathrm{TiO}_{2}$ nanoparticles on water permeability and thermal and mechanical properties of high strength self-compacting concrete. Materials Science and Engineering: A. 2010; 528(2):756-763. http://dx.doi.org/10.1016/j.msea.2010.09.074

35. Nazari A. The effects of curing medium on flexural strength and water permeability of concrete incorporating $\mathrm{TiO}_{2}$ nanoparticles. Materials and Structures. 2010; 44(4):773-786. http://dx.doi.org/10.1617/s11527-010-9664-y

36. Nazari A and Riahi S. The effects of zinc dioxide nanoparticles on flexural strength of self-compacting concrete. Composites Part B: Engineering. 2010; 42(2):167-175. http://dx.doi.org/10.1016/j. compositesb.2010.09.001

37. Nazari A and Riahi S. The effects of $\mathrm{ZnO}_{2}$ nanoparticles on split tensile strength of self-compacting concrete. Journal of Experimental Nanoscience. 2010. http://dx.doi.org/10.1080/17458080.2010.524669

38. Nazari A and Riahi S. Limewater effects on properties of $\mathrm{ZnO}_{2}$ nanoparticle blended cementitious composite. Journal of Composite Materials. 2011; 45(6):639-644. http://dx.doi.org/10.1177/0021998310376118

39. Nazari A and Riahi S. Assessment of the effects of $\mathrm{Fe}_{2} \mathrm{O}_{3}$ nanoparticles on water permeability, workability, and setting time of concrete. Journal of Composite Materials. 2011; 45(8):923-930. http://dx.doi. org/10.1177/0021998310377945

40. Nazari A and Riahi S. The effects of limewater on flexural strength and water permeability of $\mathrm{Al}_{2} \mathrm{O}_{3}$ nanoparticles binary blended concrete. Journal of Composite Materials. 2011; 45(11):1165-1172. http://dx.doi. org/10.1177/0021998310378907

41. Nazari A and Riahi S. The effects of limewater on split tensile strength and workability of $\mathrm{Al}_{2} \mathrm{O}_{3}$ nanoparticles binary blended concrete. Journal of Composite Materials. 2011; 45(9):1059-1064. http://dx.doi. org/10.1177/0021998310378909

42. Nazari A and Riahi S. The effects of $\mathrm{TiO}_{2}$ nanoparticles on properties of binary blended concrete. Journal of Composite Materials. 2011; 45(11):1181-1188. http://dx.doi.org/10.1177/0021998310378910

43. NazariA and Riahi S. Optimization mechanical properties of $\mathrm{Cr}_{2} \mathrm{O}_{3}$ nanoparticle binary blended cementitious composite. Journal of Composite Materials. 2011; 45(8):943-948. http://dx.doi.org/10.1177/0021998310377944

44. American Society for Testing and Materials - ASTM. ASTM C150: Standard Specification for Portland Cement, annual book of ASTM standards. Philadelphia: ASTM; 2001.

45. American Society for Testing and Materials - ASTM. ASTM C39: Standard Test Method for Flexural Strength of Cylindrical Concrete Specimens. Philadelphia: ASTM; 2001.

46. Abell AB, Willis KL and Lange DA. Mercury Intrusion Porosimetry and Image nalysis of Cement-Based Materials. Journal of Colloid and Interface Science. 1999; 211:39-44. PMid:9929433. http://dx.doi.org/10.1006/jcis.1998.5986

47. Tanaka K and Kurumisawa K. Development of technique for observing pores in hardened cement paste. Cement and Concrete Research. 2002; 32:1435-41. http://dx.doi.org/10.1016/S0008-8846(02)00806-2
48. Roncero J and Gettu R. Influencia de los superplastificantes en la microestructura de la pasta hidratada y en el comportamiento diferido de los morteros de cemento. Cemento Hormigón. 2002;832:12-28.

49. Hans-Ërik G and Pentti P. Properties of SCC-especially early age and long term shrinkage and salt frost resistance. In: Skarendahl Å and Petersson Ö, editors. Proceedings of the 1st international RILEM symposium on self-compacting concrete. Stockholm: RILEM Publications S.A.R.L.; 1999. p. 211-225.

50. Song HW, Byun KJ, Kim SH and Choi DH. Early-age creep and shrinkage in self-compacting concrete incorporating GGBFS. In: Ozawa $\mathrm{K}$ and Ouchi M, editors. Proceedings of the 2nd international RILEM symposium on self-compacting concrete. Tokyo: COMS Engineering Corporation; 2001. p. 413-422.

51. Hammer TA, Johansen $\mathrm{K}$ and Bjøntegaard $\emptyset$. Volume changes as driving forces to self-induced cracking of norwegian SCC. In: Ozawa K and Ouchi M, editors. Proceedings of the $2^{\text {nd }}$ international RILEM symposium on self-compacting concrete. Tokyo: COMS Engineering Corporation; 2001. p. 423-432.

52. Turcry $P$ and Loukili A. A study of plastic shrinkage of self -compacting concrete. In: Wallevik O and Nielsson I, editors. Proceedings of the $3^{\text {rd }}$ international RILEM symposium on self-compacting concrete. Reykjavik: RILEM Publications S.A.R.L.; 2003. p. 576-585.

53. Heirman $G$ and Vandewalle $L$. The influence of fillers on the properties of self-compacting concrete in fresh and hardened state. In: Wallevik $\mathrm{O}$ and Nielsson I, editors. Proceedings of the $3^{\text {rd }}$ international RILEM symposium on self-compacting concrete. Reykjavik: RILEM Publications S.A.R.L.; 2003. p. 606-618.

54. Arya $\mathrm{C}$ and $\mathrm{Xu}$ Y. Effect of cement type on chloride binding and corrosion of steel in concrete. Cement and Concrete Research. 1995; 25(4):893-902. http://dx.doi.org/10.1016/0008-8846(95)00080-V

55. Polder RB and Rooij D. Durability of marine concrete structures-field investigations and modeling. Heron. 2005; 50(3):133.

56. Glass GK, Reddy B and Buenfeld NR. Corrosion inhibition in concrete arising from its acid neutralization capacity. Corrosion Science. 2000; 42(9):1587-1598. http://dx.doi.org/10.1016/S0010-938X(00)00008-1

57. Basheer PAM, Gilleece PRV, Long AE and McCarter WJ. Monitoring electrical resistance of concretes containing alternative cementitious materials to assess their resistance to chloride penetration. Cement and Concrete Composites. 2002; 24(5):437-449. http://dx.doi.org/10.1016/ S0958-9465(01)00075-0

58. Li H, Zhang M and Ou J. Flexural fatigue performance of concrete containing nanoparticles for pavement. International Journal of Fatigue. 2007; 29(7):1292-1301. http://dx.doi.org/10.1016/j.ijfatigue.2006.10.004

59. Jawed J, Skalny J and Young JF. Hydration of Portland Cement. In: Barnes P, editor. Structure and Performance of Cements. Essex: Applied Science Publishers; 1983. p. 284-285.

60. Grzeszczyk S and Lipowski G. Effect of content and particle size distribution of high calcium fly ash on the rheological properties of cement pastes. Cement and Concrete Research. 1997; 27(6):907-916. http://dx.doi.org/10.1016/S0008-8846(97)00073-2

61. Fernandez E, Gil FJ, Ginebra MP, Driessens FCM, Planell JÁ and Best SM. Production and characterisation of new calcium phosphate bone cements in the CaHPO4-a-Ca3(PO4)2 system: $\mathrm{pH}$, workability and setting times. Journal of Materials Science: Materials in Medicine. 1999; 10:223-30. http://dx.doi.org/10.1023/A:1008958112257

62. Massazza F. The role of the additions to cement in the concrete durability. Cemento. 1987; 84:359-82.

63. National Material Advisory Board - NMAB. NMAB-437: Concrete durability: A multi-billion dollar opportunity. Washington: National Academy Press; 1987. 